\title{
Gut toxicity of 5-ASA?
}

\author{
DESMOND J LEDDIN, MD, MRCPI, MSC, FRCPC, KEVORK M PELTEKIAN, MD, FRCPC
}

D LEDDIN, KM PELTEKIAN. Gut toxicity of 5-ASA? Can J Gastroenterol $1993 ; 7(2): 170-172$. The use of enteric coated 5-ASA is contraindicated in the presence of active peptic ulceration. The basis for this is unclear. The author wished to ensure that this drug was not toxic to the gastroduodenal mucosa before proceeding with a clinical trial of a suspension of 5-ASA in the treatment of proximal Crohn's disease. A review of the literature indicated that 5-ASA protects against ischemia/reperfusion-induced damage in the rat stomach but not against ethanol-induced injury. Studies in dogs indicated that 5-ASA does not cause gastric or duodenal damage. Similarly 5-ASA did not delay gastric ulcer healing in the rat and did not inhibit gastric tissue culture synthesis of prostaglandin $E_{2}$. The current findings suggest that there is no contraindication to the use of 5-ASA in proximal Crohn's disease.

Key Words: 5-ASA, Crohn's disease, Duodenitis, Gastritis, Peptic ulceration

\section{Toxicité intestinale du 5-AAS?}

RÉSUMÉ: L'utilisation de 5-AAS à enrobage entérique est contre-indiquée en présence d'un ulcère gastro-duodénal actif. La base de cette affirmation demeure imprécise, l'auteur a voulu vérifier si ce médicament n'était pas toxique pour la muqueuse gastro-duodénale avant de procéder à un essai clinique sur une suspension de 5-AAS dans le traitement de la maladie de Crohn proximale. Une revue de la littérature a indiqué que le 5-AAS protège contre les lésions induites par la l'ischémie et la reperfusion dans l'estomac du rat, mais non pas contre les lésions induites par l'éthanol. Des études chez le chien indiquent que le 5-AAS ne cause pas de lésion gastrique ni duodénale. De même, le 5-AAS n'a pas retardé la cicatrisation d'un ulcère gastrique chez le rat. Il n'a pas inhibé la synthèse de la prostaglandine $E_{2}$ dans des cultures de tissus gastriques. Les résultats actuels suggèrent qu'il n'y a pas de contre-indications quant à l'emploi de 5-AAS dans la maladie de Crohn proximale.

Division of Gastroenterology, Dalhousie University, Halifax, Nova Scotia

Correspondence and reprints: Dr DJ Leddin, Dickson Centre, Room 4087, Victoria General Hospital, Halifax, Nova Scotia B3H 2Y9. Telephone (902) 428-2397
$\mathrm{T}$ HE USE OF 5-ASA IS CONTRAINDIcated in the presence of active peptic ulceration (1). The rationale for avoiding the drug is unclear, but may relate to the structural similarity of 5 . ASA to acetylsalicylic acid and the ability of 5-ASA to inhibit prostaglandin synthesis $(2,3)$.

Crohn's disease affecting the proximal gut is not uncommon (4). Currently there is no prepartion of 5 . ASA which will deliver high concentrations of the drug to this area. A suspension of 5-ASA, in which all of the administered drug is in contact with the gastroduodenal mucosa, may be beneficial in the treatment of proximal Crohn's disease (5). Prior to commencing a clinical trial of 5-ASA suspension in the treatment of gastroduodenal Crohn's, the author wished to investigate the effects of 5 . ASA on the proximal gut mucosa.

This paper reviews the literature on 5-ASA and the proximal gut, and presents the results of two studies on the effect of 5-ASA on canine gastro. duodenal mucosa and gastric ulcer healing in the rat.

Sulphasalazine administered subcu. taneously to rats $30 \mathrm{mins}$ prior to 10 
TABLE 1

Gastric mucosa. Sum of scores for control and 5-ASA groups

\begin{tabular}{lcc}
\hline & Control & 5-ASA \\
\hline Hyperplasia & 4.0 & 2.0 \\
Mononuclear & 6.0 & 6.0 \\
Polymorphs & 1.0 & 1.0 \\
Congestion & 1.0 & 1.0 \\
Edema & 0.0 & 0.0 \\
\hline
\end{tabular}

No significant difference between control and 5.ASA-treated groups

\section{TABLE 2}

Duodenal mucosa. Sum of scores for control and 5-ASA groups

\begin{tabular}{lcc}
\hline & Control & 5-ASA \\
\hline Edema & 0.0 & 0.0 \\
Congestion & 4.0 & 7.0 \\
Degeneration & 2.0 & 4.0 \\
Brush & 2.0 & 3.0 \\
Mitosis & 0.0 & 2.0 \\
G cells & 6.0 & 6.0 \\
LP cells & 2.0 & 3.0 \\
\hline
\end{tabular}

No significant difference between control and 5.ASA-treated groups

$\mathrm{mL} / \mathrm{kg} 40 \%$ ethanol by mouth protected against ethanol-induced gastric damage (6). The protective action was due to sulphapyridine; 5-ASA was without effect. Sulphapyridine, but not 5.ASA, preserved gastric mucus content following administration of $40 \%$ ethanol.

In rats, 30 mins of hypovolemia (followed by normalization of blood volume) resulted in increased red blood cell clearance into the lumen of the stomach, gross morphological damage and histological lesions in the gastric mucosa (7). Perfusion of the stomach with a solution containing $30 \mathrm{mM} 5$. ASA reduced red cell leakage and the extent of mucosal damage following ischemia/reperfusion. Sulphapyridine was not effective. Neither 5-ASA nor sulphapyridine was effective in preventing histological abnormalities. The effect of 5-ASA was not due to aterations in mucosal bloodflow because 5-ASA did not affect mucosal bloodflow either in the control or ischemic periods. The mechanism of protection was postulated to be scavenging of hydroxyl radicals by 5 -ASA because the effect of 5-ASA was similar to that

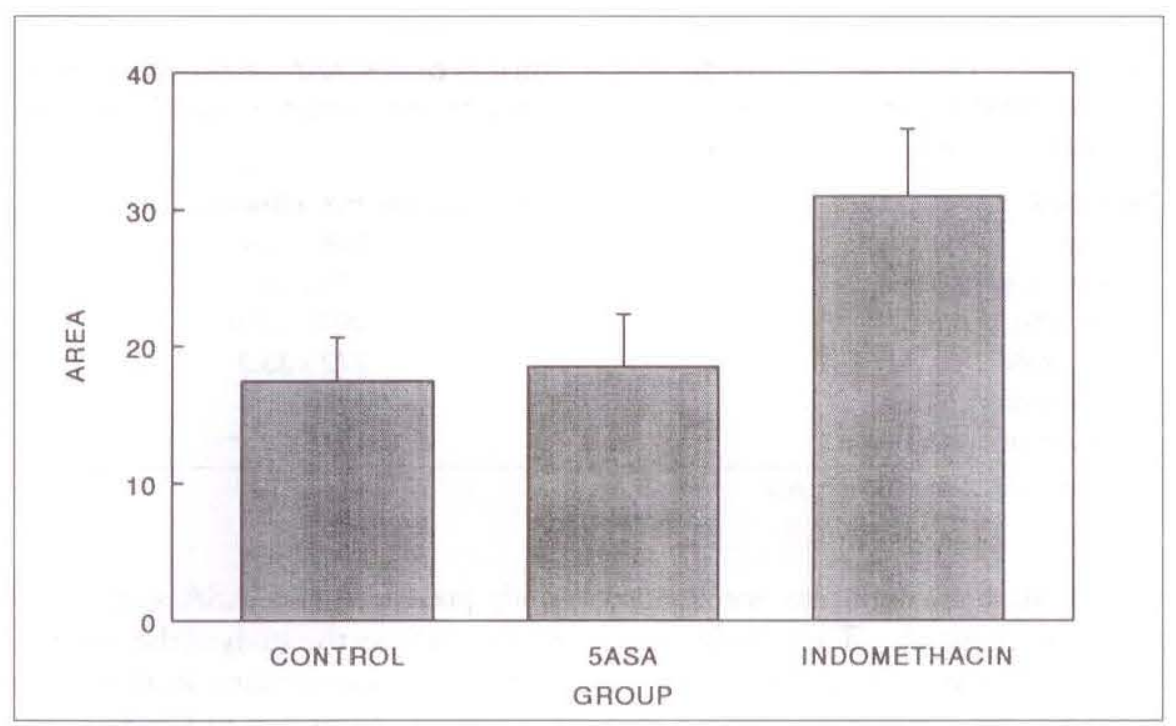

Figure 1) The effect of oral administration of 5-ASA and indomethacin on ulcer area in the rat 10 days post induction of the ulcer. Results are shown as mean \pm SEM area

of dimethylsulphoxide, a hydroxyl radical scavenger.

It appears, therefore, that in acute experiments in the rat, 5-ASA ameliorates ischemia/reperfusion gastric injury and does not affect ethanolinduced damage.

In order to determine whether 5 ASA is capable of producing mucosal damage when given orally as suspension for a longer time, 12 female beagles were randomized to treatment with placebo or a suspension of 5-ASA at a dosage of $40 \mathrm{mg} / \mathrm{kg}$ bid by gavage. Following treatment for 10 days, animals were sacrificed and the gut was removed.

No gross lesions were observed in the esophagus, stomach, small intestine or colon in either the control or 5-ASA groups. The mucosa was examined histologically. Abnormalities were scored: 1 for mild, 2 for moderate and 3 for severe. The abnormalities within groups were summed for analysis. Minor abnormalities were seen in both the placebo group and the 5-ASAtreated animals (Tables 1,2). There was no significant difference between the groups with regard to histological abnormalities; neither was there microscopic evidence of gastritis, duodenitis, erosions or ulceration despite a peak serum 5 -ASA level of $42.9 \pm 3.8 \mathrm{~g} / \mathrm{mL}$ more than 20 times that reported following administration of approximate- ly $7 \mathrm{mg} / \mathrm{kg}$ of enteric coated 5 -ASA by mouth to human volunteers (8). 5 . ASA did not cause the changes which have been described following administration of acetylsalicylic acid to dogs (9).

The effect of 5-ASA on gastric ulcer healing was compared with indomethacin and placebo. Ulcers were induced in the gastric bod by application of a cryoprobe at $-60^{\circ} \mathrm{C}$ to the gastric serosa for $40 \mathrm{~s}$. The animals were randomly assigned to treatment with placebo (methylcellulose suspension) orally, indomethacin $2.5 \mathrm{mg} / \mathrm{kg}$ orally bid or 5 -ASA $40 \mathrm{mg} / \mathrm{kg}$ orally bid. Ten days after ulcer induction, animals were sacrificed and the area of ulcers was measured by computerized planimetry. The results are shown in Figure 1. The mean \pm sem ulcer area in the placebo group was $17.52 \pm 3.2 \mathrm{~mm}^{2}$; for 5 -ASA it was $18.54 \pm 3.89$ and for indomethacin it was $31.00 \pm 4.90$. Ulcer area was significantly greater in the animals receiving indomethacin $(\mathrm{P}<0.05)$ compared with controls. 5-ASA did not delay ulcer healing $(\mathrm{P}=0.84)$.

Since nonsteroidal anti-inflammatory drugs mediate their effects on the gastric mucosa, at least in part by inhibition of prostaglandin (PG) synthesis, the effect of 5-ASA on gastric $\mathrm{PGE}_{2}$ synthesis was studied following tissue culture of strips of rat gastric mucosa. PGE2 was measured by radio- 


\section{TABLE 3}

The effect of dimethylsulphoxide, indomethacin and 5-ASA on gastric prostaglandin (PG) $E_{2}$ synthesis. Results are shown as the mean \pm sem in $\mathrm{pg} / \mathrm{mg}$ gastric tissue per hour

\begin{tabular}{lc}
\hline Treatment & Prostaglandin synthesis $\mathbf{p g} / \mathbf{m g} / \mathbf{h}$ \\
\hline Control & $348 \pm 55.9$ \\
Dimethylsulphoxide & $325 \pm 44.9$ \\
5 -ASA $100 \mu \mathrm{M}$ & $411 \pm 137.0$ \\
$5-\mathrm{ASA} 1 \mathrm{mM}$ & $272 \pm 35.0$ \\
Indomethacin $100 \mu \mathrm{M}$ & $194 \pm 62.4$ \\
Indomethacin $1 \mathrm{mM}$ & $193 \pm 24.1^{*}$ \\
\hline
\end{tabular}

-Significantly different from control

immunoassay in duplicate specimens from four animals. The results are shown in Table 3 . The drugs were suspended in dimethylsulphoxide.

Synthesis of $\mathrm{PGE}_{2}$ in the control group was not different from treatment of the tissue with dimethylsulphoxide alone. 5-ASA at concentrations of 100 $\mu \mathrm{M}$ and $1 \mathrm{mM}$ did not significantly reduce $\mathrm{PGE}_{2}$ synthesis. Indomethacin significantly decreased gastric $\mathrm{PGE}_{2}$ synthesis at a concentration of $1 \mathrm{mM}$.

5-ASA has been reported to both inhibit (10) and stimulate (11) colonic $\mathrm{PGE}_{2}$ synthesis at concentrations similar to those used in this study. The difference in results likely reflects differences in methodology and concentration of the drug.

\section{CONCLUSIONS}

In summary, there is no evidence from the available literature, from the study presented of 5-ASA suspension in dogs or from the study of the effect of 5-ASA on ulcer healing in the rat to contraindicate its use in Crohn's disease of the proximal intestine.

ACKNOWLEDGEMENTS: The author wishes to acknowledge the contribution of Drs J Blay, S Craig, D Malatjalian and D Paley to the completion of these studies which were funded by Interfalk Canada Inc.

\section{REFERENCES}

1. Compendium of Pharmaceuticals and Specialties, 26th edn. Ottawa: Canadian Pharmaceutical Association, 1991.

2. Collier HOJ, Alison AF, McDonaldGibson WJ, et al. Inhibition of prostaglandin biosynthesis by sulphasalazine and its metabolites. Prostaglandins 1976;11:219-25.

3. Sharon P, Ligumsky M, Rachmilewitz $\mathrm{D}$, et al. Role of prostaglandins in ulcerative colitis. Gastroenterology 1978;75:638-40.

4. Cameron DJ. Upper and lower gastrointestinal endoscopy in children and adolescents with Crohn's disease A prospective study. J Gastroenterol Hepatol 1991;6:355-8.

5. Williams CN, Morgan E.

Pharmacokinetics of 5-aminosalicylic acid enteral suspension in Crohn's disease patients and normal volunteers Can J Gastroenterol 1990;4:458-62.

6. Cho $\mathrm{CH}$, Ogle CW, Sevilla EL. The protective effects of sulphasalazine against ethanol-induced gastric damage in rats. $\mathrm{Br}$ J Pharmacol 1987;92:31-7.

7. Kvietys PR, Smith SM, Girsham MB, et al. 5-Aminosalicylic acid protects against ischemia/reperfusion-induced gastric bleeding in the rat.

Gastroenterol 1988:94:733-8.

8. Norlander B, Gotthard R, Strom M. Steady-state pharmacokinetics of enteric coated 5-aminosalicylic acid tablets in healthy volunteers and in patients with Crohn's disease or ulcerative colitis, Aliment Pharmacol Therap 1991;5:291-300.

9. Ashley SW, Sonnenschein LA, Cheung LY. Focal mucosal blood flow at the site of aspirin-induced ulceration. Am J Surg 1985;149:53-9.

10. Hawkey CJ, Boughton-Smith NK, Whittle BJR. Modulation of human colonic arachidonic acid metabolism by sulphasalazine. Dig Dis Sci 1985;30:1161-5.

11. Kolassa N, Becker R, Wiener H. Influence of sulphasalazine, 5-aminosalicylic acid and sulphapyridine on prostanoid synthesis and metabolism in rabbit colonic mucosa. Prostaglandins 1985;29:133-42. 


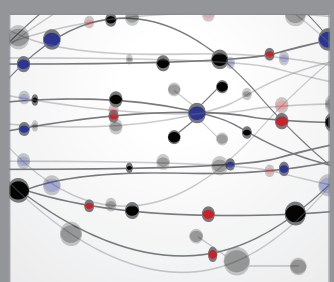

The Scientific World Journal
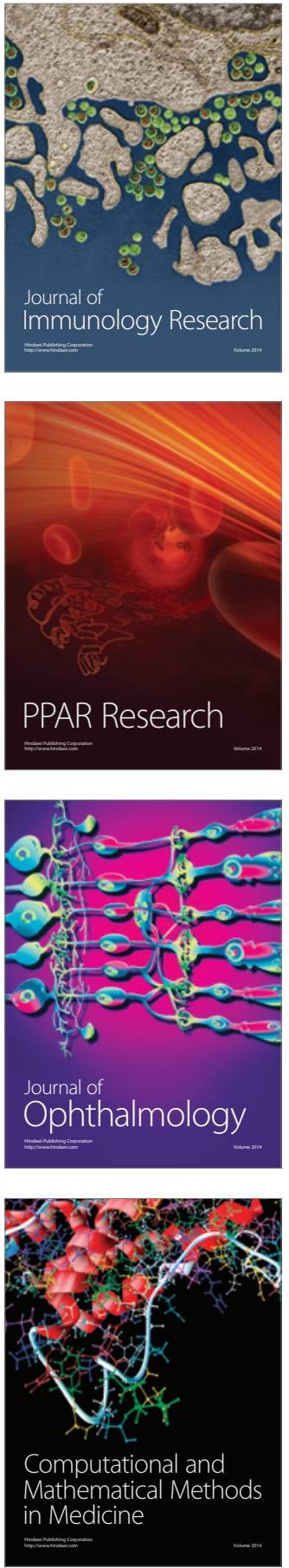

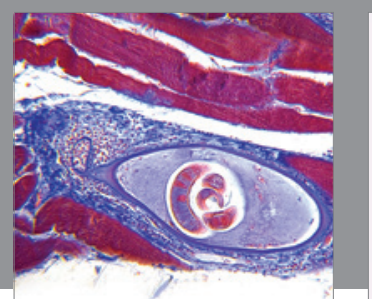

Gastroenterology Research and Practice

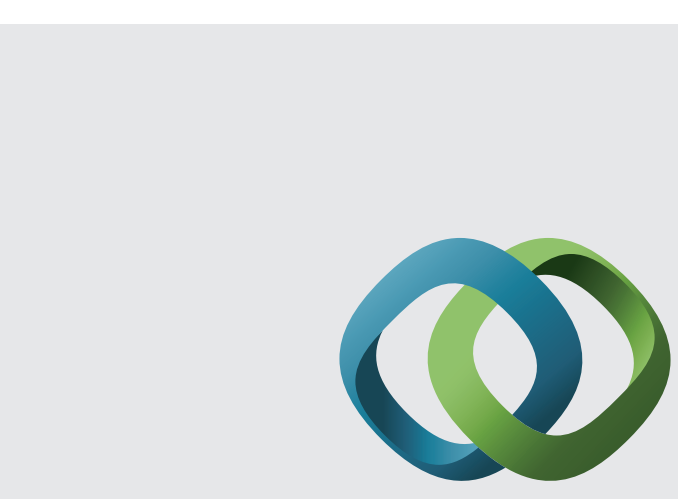

\section{Hindawi}

Submit your manuscripts at

http://www.hindawi.com
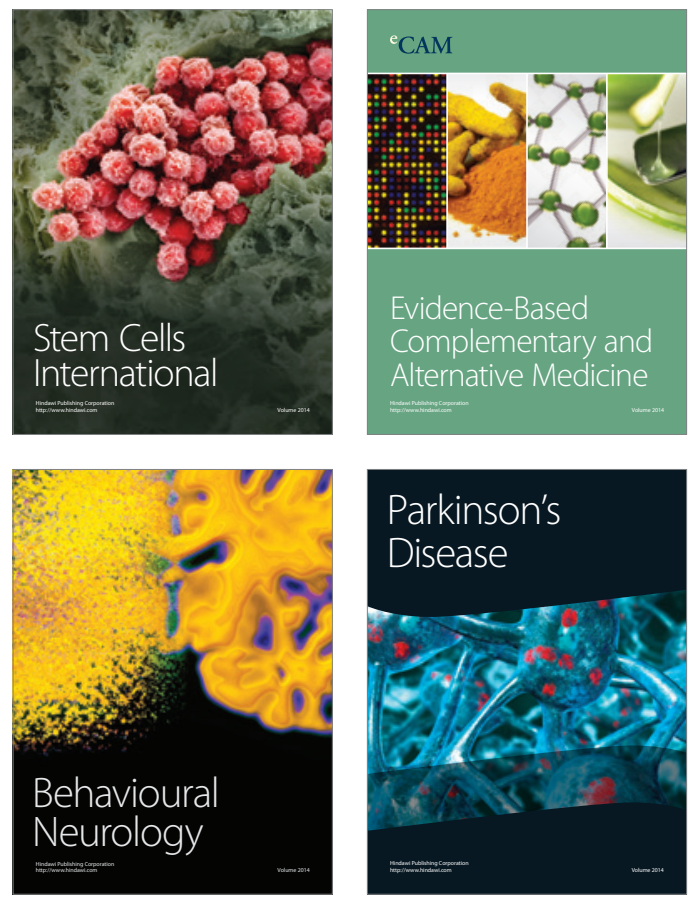
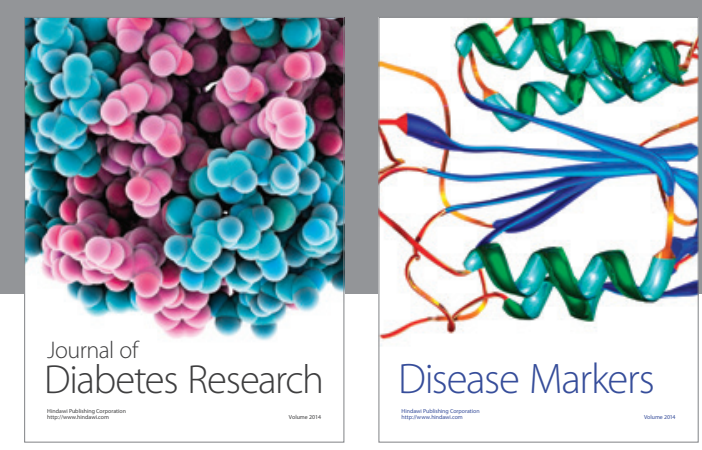

Disease Markers
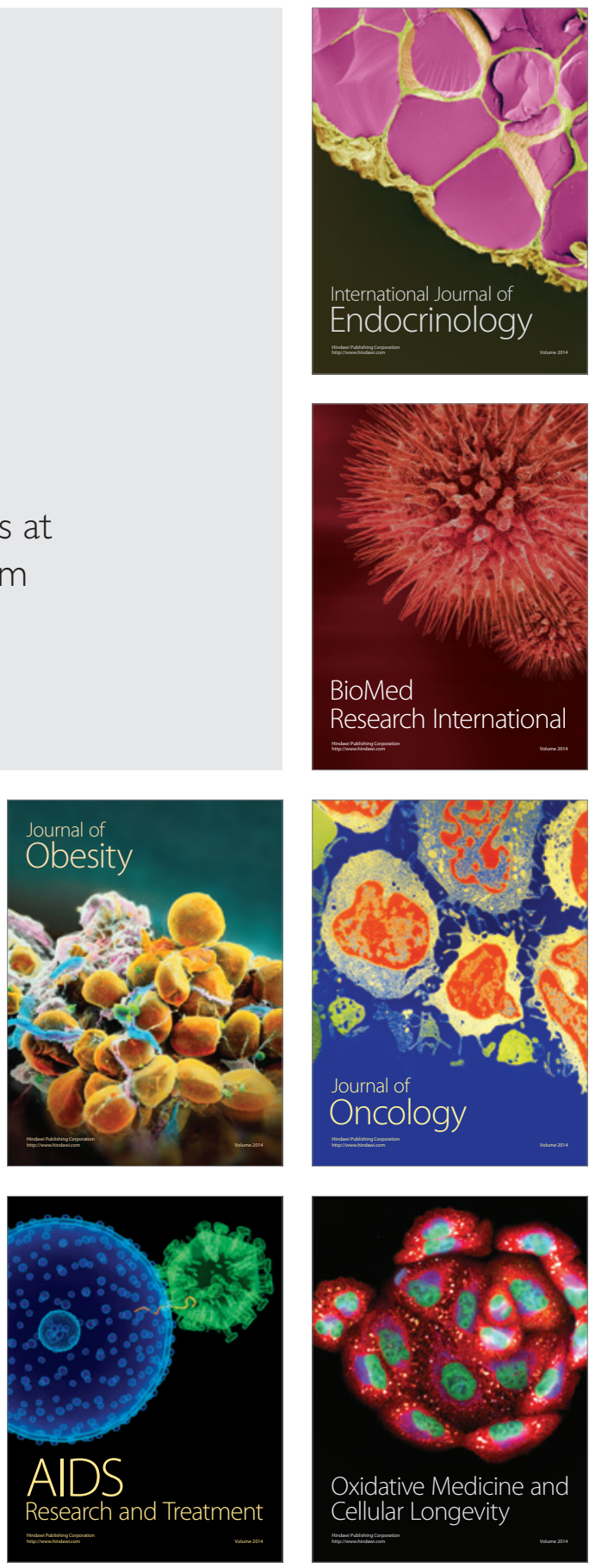